\title{
СТАН ПЕРОКСИДНОГО ОКИСНЕННЯ ЛІПІДІВ ТА АНТИОКСИДАНТНИЙ ЗАХИСТ ПРИ ЕКСПЕРИМЕНТАЛЬНІЙ НЕОПЛАСТИЧНІЙ ІНТОКСИКАЦІЇ
}

Вступ. Актуальним є питання дослідження дисбалансу між процесами пероксидного окиснення ліпідів та антиоксидантного захисту. Такий дисбаланс викликає порушення метаболізму, утворення пероксидів, кетонів, альдегідів, його вважають основою механізму розвитку ендогенної інтоксикації.

Мета дослідження - вивчити ступінь активації пероксидного окиснення ліпідів і стан антиоксидантного захисту при синдромі неопластичної інтоксикації.

методи дослідження. Використано фрармакологічні, морфологічні методи і методи математичної статистики. Експериментальне фрармакологічне дослідження виконано на білих щурах масою 170-180 г у Центральній науково-дослідній лабораторії Тернопільського національного медичного університету імені І. Я. Горбачевського МОЗ України (свідоцтво про атестацію № 023/13 від 05.03.2020 р.) згідно з методичними рекомендаціями Державного експертного центру МОЗ України. При проведенні дослідження враховували такі біохімічні показники крові: активність дієнових і трієнових кон'югатів, середньомолекулярних пептидів (при довжині хвилі 254 та 280 нм), активних продуктів тіобарбітурової кислоти, супероксиддисмутази і каталази. Тварин, яких включили в дослідження, поділили на 2 групи: 1-ша - контрольна; 2-га - позитивна патологія; дослідження тривало 30 днів. Моделювали патологічні процеси та виводили щурів з експерименту, дотримуючись вимог біоетики, правил належної лабораторної практики, і згідно з етичними нормами Європейської конвенції про захист хребетних тварин, що використовуються для дослідних та інших наукових цілей.

Результати й обговорення. Під час дослідження було встановлено зростання біохімічних показників - дієнових і трієнових кон'югатів, активних продуктів тіобарбітурової кислоти, що вказувало на активацію процесу пероксидного окиснення ліпідів. Активність супероксиддисмутази мала коливальний характер і до кінця експерименту зменшилась на 16,5\%. Активність каталази під час експерименту збільшилась. Показники MCM $_{254}$ і MCM $_{280}$ підвищились, що свідчило про наростання проявів ендогенної інтоксикації.

Висновок. При синдромі неопластичної інтоксикації у крові спостерігають поступове надмірне утворення продуктів вільнорадикального окиснення в поєднанні з компенсаторною активацією ензимних ланок антиоксидантної системи. кація.

КЛЮЧОВІ СЛОВА: пероксидне окиснення ліпідів; антиоксидантний захист; неопластична інтокси-

ВСТУП. Процеси пероксидного окиснення ліпідів (ПОЛ) проходять у всіх клітинах живих організмів та забезпечують нормальне фрунціонування біохімічних, метаболічних і фізіологічних систем [1]. Пероксидне окиснення ліпідів відіграє важливу роль у формуванні неспецифрічної резистентності організму, гомеостазу, регенерації тканин [2]. Стан ПОЛ підтримується на стабільному рівні завдяки фрункціонуванню системи антиоксидантного захисту (АОЗ) організму на різних рівнях організму [3]. Порушення роботи (c) П. Я. Боднар, І. М. Кліщ, Я. Я. Боднар, Т. В. Боднар, Ю. В. Сорока, 2021. системи ПОЛ викликає збільшення проникності мембран та їх набряк, руйнування клітинних органел і клітин, потрапляння токсичних продуктів метаболізму до внутрішніх середовищ організму. Активацію ПОЛ спричиняють гіпоксія та запалення [4]. Порушення балансу в системі пОЛ - АОЗ є основою патогенезу ендогенної інтоксикації, яка ускладнює перебіг багатьох захворювань [5].

Динамічна рівновага системи ПОЛ - АОЗ є основним показником, що забезпечує адаптаційні можливості організму [6]. У наукових роботах 
сучасних учених П. Я. Боднара, Н. Є. Лісничук висвітлено особливості біохімічних показників і стану згортальної системи крові за умов хронічної неопластичної інтоксикації [1]. У праці науковців Т. Д. Звягінцевої і С. В. Гріднєвої зібрано сучасні підходи до діагностики хронічних захворювань кишечника на основі показників ПОЛ та АОЗ у крові й слизовій оболонці товстої кишки [7]

У зв'язку з великою кількістю досліджень системи гомеостазу, фрахівець охорони здоров'я відчуває необхідність отримати знання щодо динаміки показників ПОЛ при синдромі неопластичної інтоксикації для їх використання в практичній діяльності. Наукове дослідження таких даних значно спростить та допоможе практичному лікарю виконувати свої функції.

Мета дослідження - вивчити ступінь активації пероксидного окиснення ліпідів і стан антиоксидантного захисту при синдромі неопластичної інтоксикації.

МЕТОДИ ДОСЛІДЖЕННЯ. Експериментальне фрармакологічне дослідження виконано на 12 статевозрілих нелінійних щурах-самцях масою 170-180 г у Центральній науково-дослідній лабораторії Тернопільського національного медичного університету імені І. Я. Горбачевського МОЗ України (свідоцтво про атестацію № 023/13 від 05.03.2020р.) згідно з методичними рекомендаціями Державного експертного центру МОЗ України [8]. Щурів, включених у дослідження, вирощували у віварії, і перед початком експерименту вони проходили акліматизацію в умовах кімнати для проведення випробувань протягом 7 днів, тварини отримували стандартний збалансований корм. Моделювали патологічні процеси і виводили щурів з експерименту з дотриманням вимог біоетики, правил належної лабораторної практики (GLP) та згідно з етичними нормами Європейської конвенції про захист хребетних тварин, що використовуються для дослідних та інших наукових цілей (Страсбург, 1986) [9]. Хронічну неопластичну інтокси- кацію викликали шляхом введення 1,2-диметилгідразин гідрохлориду (фрірма "Sigma-Aldrich Chemie”, виробництво Японії, серія D161802), попередньо розведеного ізотонічним розчином натрію хлориду. Канцероген вводили підшкірно в міжлопаткову ділянку в дозі 7,2 мг/кг 1 раз на тиждень упродовж 30 тижнів, відповідно до маси тварини - 3 розрахунку 0,1 мл розчину 1,2-диметилгідразин гідрохлориду на 10 г маси тіла щура [1]. Летальність становила 33 \%. Протягом 30 днів загинули 4 тварини. При проведенні дослідження враховували такі біохімічні показники крові: активність дієнових (ДК) і трієнових кон'югатів (ТК) [10, 11], середньомолекулярних пептидів (молекул середньої маси фрракцій, що визначались при довжині хвилі 254 і 280 нм, $\mathrm{MCM}_{254}$ та $\mathrm{MCM}_{280}$ відповідно) [12, 13], ТБК-активних продуктів (ТБК-АП), супероксиддисмутази (СОД) і каталази (КАТ) [14-16]. Після закінчення лікування тварин виводили з експерименту за умов евтаназії (декапітація під есрірним наркозом) згідно з вимогами біоетики та оцінювали стан системи ПОЛ - АОЗ.

Клінічні результати дослідження було оброблено за допомогою методів математичної статистики із застосуванням програмного забезпечення Microsoft Excel. При нормальному розподілі вибірки статистичну значимість визначали 3 використанням t-критерію Стьюдента, при ненормальному розподілі-за U-критерієм Манна Уїтні [17].

РЕЗУЛЬТАТИ Й ОБГОВОРЕННЯ. У РЕЗУЛЬтаті дослідження було встановлено лише тенденцію до зростання біохімічних показників ПОЛ, порівняно з контрольними даними, на 5-й день експерименту (табл.).

Як свідчать результати дослідження, на 5-й день експерименту активність ДК зросла на 1,83\%, ТК - на 0,8\%, ТБК-активних продуктів на 1,94 \%. На 10-й день дослідження спостерігали достовірне підвищення активності ДК на $35,8 \%$, ТК - на 40,8 \%, ТБК-АП - на 33,6 \%

\section{Таблиця - Показники пероксидного окиснення ліпідів і антиоксидантного захисту}

сироватки крові при синдромі неопластичної інтоксикації (M士m)

\begin{tabular}{|c|c|c|c|c|}
\hline \multirow{2}{*}{ Показник } & \multirow{2}{*}{ Контроль (n=12) } & \multicolumn{3}{|c|}{ "Термін експерименту, дні } \\
\hline & & 5-й день (n=12) & 10-й день (n=12) & 30-й день (n=8) \\
\hline ДК, ммоль/л & $1,09 \pm 0,08$ & $1,11 \pm 0,04$ & $1,48 \pm 0,04^{\star \star}$ & $2,30 \pm 0,07^{\star \star \star}$ \\
\hline ТК, ммоль/л & $1,25 \pm 0,09$ & $1,26 \pm 0,05$ & $1,76 \pm 0,12^{\star \star}$ & 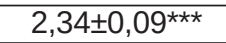 \\
\hline ТБК-АП, ммоль/л & $3,60 \pm 0,04$ & $3,67 \pm 0,07$ & $4,81 \pm 0,05^{\star \star \star}$ & $5,89 \pm 0,13^{\star \star \star}$ \\
\hline СОД, ум. од. & $48,15 \pm 0,67$ & $48,16 \pm 0,68$ & $52,12 \pm 0,60^{*}$ & $43,51 \pm 1,02^{*}$ \\
\hline КАТ, мкат/л & $43,02 \pm 1,03$ & $43,94 \pm 1,02$ & $49,02 \pm 1,02^{\star \star}$ & $45,80 \pm 0,91^{*}$ \\
\hline $\mathrm{MCM}_{254}$ & $0,022 \pm 0,001$ & $0,024 \pm 0,001^{*}$ & $0,026 \pm 0,001^{\text {** }}$ & $0,027 \pm 0,001^{\star \star \star}$ \\
\hline $\mathrm{MCM}_{280}$ & $0,019 \pm 0,001$ & $0,025 \pm 0,001^{\star \star \star}$ & $0,027 \pm 0,001^{\star \star \star}$ & $0,032 \pm 0,001^{\star \star \star}$ \\
\hline
\end{tabular}

Примітка. * - величини, які статистично достовірно відрізняються від аналогічних показників у контрольній групі тварин: * $-p<0,05 ;{ }^{*}-p<0,01 ;{ }^{* *}-p<0,001$. 
відносно контрольної групи. На 30-й день експерименту також відзначали достовірне зростання досліджуваних показників ПОЛ: ДК - на 111 \%, ТК - на 87,2 \%, ТБК-АП - на 63,6 \% щодо контрольної групи порівняно $з$ даними 1-го тижня експериментальної групи. Така динаміка показників свідчила про активацію процесу пероксидного окиснення.

При аналізі основних ензимів АОЗ було встановлено, що активність СОД мала коливальний характер та до кінця експерименту знизилася на $16,5 \%$ відповідно до максимального зростання і на 9,6 \% відносно контрольної групи (табл.).

Активність КАТ у сироватці крові на 5-й день експерименту мала тенденцію до підвищення, проте достовірно не відрізнялась від контрольної групи. Загалом було виявлено достовірне ії зростання на 11,6 \% відносно 5-го дня дослідження і тенденцію до зниження на 30-й день порівняно з попереднім терміном (табл.).

Активність $\mathrm{MCM}_{254}$ у сироватці крові під час дослідження достовірно збільшилася $(p<0,001)$. Зокрема, на 5-й день цей показник зріс на 10,4 \%, на 10-й - на 16,6 \%, на 30-й - на 20,5 \% відносно контрольної групи. Дані значення статистично достовірно відрізнялись між собою. Активність MCM $_{280}$ під час спостереження достовірно зростала в усі терміни спостереження і була найвищою на 30-й день, тобто на 68,2 \% щодо контрольної групи $(p<0,001)$. Достовірне збільшення у крові активності MCM $_{254}$ і MCM $_{280}$ протягом 30 днів експериментальної неопластичної інтоксикації свідчило про наростання проявів ендогенної інтоксикації.

У сироватці крові за умови синдрому неопластичної інтоксикації спостерігали поступове надмірне утворення продуктів вільнорадикального окиснення в поєднанні з компенсаторною активацією ензимних ланок антиоксидантної системи в початковий період експерименту і поступовим її виснаженням, починаючи 3 10-го дня, що підтверджувалося достовірним зниженням активності СОД і КАТ у сироватці крові до кінця дослідження відносно результатів контрольної групи $(p<0,001)$.

ВИСНОВКИ. 1. У результаті дослідження було встановлено зростання таких біохімічних показників крові-дієновихі трієнових кон'югатів, ТБК-активних продуктів, що свідчить про активацію процесу пероксидного окиснення.

2. При аналізі показників супероксиддисмутази було встановлено, що її активність мала коливальний характер і до кінця експерименту знизилася на 16,5\%.

3. При дослідженні активності каталази було встановлено ії зростання під час експерименту.

4. При вивченні показників $\mathrm{MCM}_{254}$ i $\mathrm{MCM}_{280}$ було виявлено їх підвищення, що свідчить про наростання проявів ендогенної інтоксикації.

5. При синдромі неопластичної інтоксикації у крові спостерігали поступове надмірне утворення продуктів вільнорадикального окиснення в поєднанні 3 компенсаторною активацією ензимних ланок антиоксидантної системи.

Перспективи подальших досліджень. 3 метою регуляції біохімічних процесів перспективною та актуальною є розробка методів корекції надлишкової інтенсифрікації пероксидного окиснення ліпідів і системи антиоксидантного захисту.

\section{СПИСОК ЛІТЕРАТУРИ}

1. Оцінка біохімічних показників і стану згортальної системи крові щурів за умов хронічної неопластичної інтоксикації / П. Я. Боднар, Н. Є. Лісничук // Мед. та клініч. хімія. -2019. -21, № 4 (82). - С. 83-88.

2. Лотоцька О. В. Перекисне окиснення ліпідів та антиоксидантний захист в організмі піддослідних тварин під впливом субтоксичних доз міді на фоні вживання питної води з різним вмістом стеарату калію / О. В. Лотоцька // Актуальні проблеми транспортної медицини. - 2013. - № 3 (33). - С. 139-145.

3. Бондаренко Ю. В. Стан перекисного окиснення ліпідів та антиоксидантної системи після оперативних втручань з приводу механічної жовтяниці / Ю. В. Бондаренко // Практика і досвід. - 2008. - № 4. - С. 52-54.

4. Регеда М. С. Вплив корвітину на показники перекисного окиснення ліпідів та антиоксидантну систему в легенях у динаміці розвитку експериментального алергічного альвеоліту в умовах стресу / М. С. Регеда, М. Є. Ковальська // Вісн. наук. дослідж. 2018. - № 1. - С. 118-122.

5. Мудра У. О. Ендогенна інтоксикація, пероксидне окиснення ліпідів та антиоксидантна система організму в хворих на подагру на тлі неалкогольного стеатогепатиту / У. О. Мудра, С. М. Андрейчин // Мед. та клініч. хімія. - 2019. - 21, № 3 (81). - С. 64-70.

6. Боброннікова Л. Р. Система ПОЛ - АОЗ за коморбідного поєднання хронічного безкам'яного холециститу та гіпертонічної хвороби / Л. Р. Боброннікова // Сучасна гастроентерологія. - 2008. - № 2 (40). C. 14-16.

7. Звягінцева Т. Д. Сучасні підходи до діагностики хронічних захворювань кишечнику / Т. Д. Звягінцева, 
С. В. Гріднєва // Укр. тер. журн. - 2005. - № 2. C. 44-48.

8. Стесранов О. В. Доклінічні дослідження лікарських засобів : метод. рек. / за ред. О. В. Стефранова. К. : Авіцена, 2001. - 528 с.

9. European convention for the protection of vertebrale animals used for experimental and other scientific purposes. - Council of Europe, Strasbourg, 1986. $-53 p$.

10. Методическое пособие по изучению процессов перекисного окисления липидов и системы антиоксидантной защиты организма животных / [В. С. Бузлама, М. И. Рецкий, Н. П. Мещеряков и др.]. -Воронеж, 1997. - 35 c

11. Колесова О. Е. Перекисное окисление липидов и методы определения продуктов липопероксидации в биологических средах / О. Е. Колесова, А. А. Маркин, Т. Н. Федорова // Лаб. дело. - 1984. № 9. - С. 540-546.

12. Габриэлян Н. И. Скрининговый метод определения средних молекул в биологических жидкостях : метод. рек. / Н. И. Габриэлян, Э. Р. Левицкий, А. А. Дмитриев. - М., 1985. - 22 с.

13. Попов Т. Метод определения пероксидазной активности крови / Т. Попов, Л. Нейковска // Гигиена и санитария. - 1971. - № 10. - С. 89-93.

14. Королюк М. А. Метод определения активности каталазы / М. А. Королюк, Л. И. Иванова, И. Г. Майорова // Лаб. дело. - 1988. - № 1. - С. 16-18.

15. Николайчик В. В. "Средние молекулы" - образование и способы определения /В.В.Николайчик, В. В. Кирковский, В. М. Маин // Лаб. дело. - 1989. № 8. - C. 31-33.

16. Caveolin-1 inhibits expression of antioxidant enzymes through direct interaction with nuclear erythroid 2 p45-related factor-2 (Nrf2) / W. Li, H. Liu, J. S. Zhou [et al.] // J. Biol. Chem. -2012. -287, No. 25. - P. 2092220930

17. Біостатистика : підручник / [В. Ф. Москаленко, О. П. Гульчій, М. В. Голубчиков та ін.] ; за ред. В. Ф. Москаленка. - К. : Книга плюс, 2009. - 184 с.

\section{REFERENCES}

1. Bodnar, P. Y., \& Lisnychuk, N.Y. (2020). Otsinka biokhimichnykh pokaznykiv i stanu zhortalnoi krovi shchuriv za umov khronichnoi neoplastychnoi intoksykatsii [Assessment of biochemical indices and condition of coagulated blood system in chronic neoplastic intoxication]. Medychna i klinichna khimiia - Medical and Clinical Chemistry, (4), 83-88. Retrieved from: https://doi. org/10.11603/mcch.2410-681X.2019.v.i4.10843 [in Ukrainian].

2. Lototska, O.V. (2013). Perekysne okysnennia lipidiv ta antyoksydantnyi zakhyst $v$ orhanizmi piddoslidnykh tvaryn pid vplyvom subtoksychnykh doz midi na foni vzhyvannia pytnoi vody z riznym vmistom stearatu kaliiu [Lipid peroxidation and antioxidant protection in experimental animals under the influence of subtoxic doses of copper on the background of drinking water with different content of potassium stearate]. Aktualni problemy transportnoi medytsyny - Current Problems of Transport Medicine, 3 (33), 139-145 [in Ukrainian].

3. Bondarenko, Yu.V. (2008). Stan perekysnoho okysnennia lipidiv ta antyoksydantnoi systemy pislia operatyvnykh vtruchan z pryvodu mekhanichnoi zhovtianytsi [The state of lipid peroxidation and the antioxidant system after surgical interventions for mechanical jaundice]. Praktyka i dosvid - Practice and Experience, 4, 52-54 [in Ukrainian].

4. Regeda, M.S., \& Kovalska, M.Y. (2018). Vplyv korvitynu na pokaznyky perekysnoho okysnennia lipidiv ta antyoksydantnu systemu $v$ leheniakh u dynamitsi rozvytku eksperymentalnoho alerhichnoho alveolitu $v$ umovakh stresu [Effect of corvitin on lipid peroxidation and the antioxidant system in the lungs in the dynamics of experimental allergic alveolitis under stress]. Visnyk naukovykh doslidzhen - Bulletin of Scientific Research, (1), 118-122. Retrieved from: https://doi.org/10.11603/24158798.2018.1.8746 [in Ukrainian].
5. Mudra, U.O., \& Andreichyn, S.M. (2019). Endohenna intoksykatsiia, peroksydne okysnennia lipidiv ta antyoksydantna systema orhanizmu v khvorykh na podahru na tli nealkoholnoho steatohepatytu [Endogenous intoxication, lipid peroxidation and antioxidant system in gout patients with non-alcoholic steatohepatitis]. Medychna ta klinichna khimiia - Medical and Clinical Chemistry, 3, 64-70 [in Ukrainian].

6. Bobronnikova, L.R. (2008). Systema POL-AOZ za komorbidnoho poiednannia khronichnoho bezkamianoho kholetsystytu ta hipertonichnoi khvoroby [POLAOZ system for comorbid combination of chronic calculous cholecystitis and hypertension]. Suchasna hastroenterolohiia - Modern Gastroenterology, (2) 40, 14-16 [in Ukrainian].

7. Zviahintseva, T.D., \& Hrydnieva, S.V. (2005). Suchasni pidkhody do diahnostyky khronichnykh zakhvoriuvan kyshechnyku [Modern approaches to the diagnosis of chronic intestinal diseases]. Ukrainskyi terapevtychnyi zhurnal - Ukrainian Therapeutic Journal, (2), 44-48 [in Ukrainian].

8. Stefanov, O.V. (2001). Doklinichni doslidzhennia likarskykh zasobiv: metodychni rekomendatsii [Preclinical studies of drugs: guidelines]. Kyiv: Avitsena [in Ukrainian].

9. Council of Europe. (1993). European Convention for the Protection of Vertebrate Animals used for Experimental and other Scientific Purposes: explanatory report on the convention opened for signature on 18 March 1986. Council of Europe Press.

10. Buzlama, V.S., Reckij, M.I., Meshherjakov, N.P., \& Rogacheva, T.E. (1997). Metodicheskoe posobie po izucheniyu protsessov perekisnogo okisleniya lipidov i sistemy antioksidantnoy zashchity organizma u zhivotnykh [Methodological manual for the study of lipid peroxidation processes and the antioxidant defense system of animals]. Voronezh [in Russian]. 
11. Kolesova, O.E., Markin, A.A., \& Fedorova, T.N. (1984). Perekisnoe okislenie lipidov i metody opredeleniya produktov lipoperoksidatsii $v$ biologicheskikh sredakh [Lipid peroxidation and methods for the determination of lipid peroxidation products in biological media]. Laboratornoe delo - Laboratory Business, (9), 540-546 [in Russian].

12. Gabrijeljan, N.I., Levickij, Je.R., \& Dmitriev, A.A. (1985). Skriningovyy metod opredeleniya srednikh molekul v biologicheskikh zhidkostyakh. Metodicheskie rekomendatsii [Screening method for the determination of medium molecules in biological fluids. Guidelines]. Moscow [in Russian].

13. Popov, T., \& Nejkovskaja, L. (1971). Metod opredeleniya peroksidaznoy aktivnosti krovi [Method for determination of blood peroxidase activity]. Gigiena Sanitariya - Hygiene and Sanitary, 10, 89-91 [in Russian].
14. Koroljuk, M.A., Ivanova, L.K., Majorova, I.G., \& Tokareva, V.A. (1988). Metod opredeleniya aktivnosti katalazy [Method for determination of catalase activity]. Laboratornoe delo - Laboratory Business, (4), 44-47 [in Russian].

15. Nikolajchik, V.V., Kirkovskij, V.V., \& Moin, V.M. (1989). «Srednie molekuly»-obrazovanie i sposoby opredeleniya ["Medium molecules" - formation and methods of determination]. Laboratornoe delo - Laboratory Business, (8), 31 [in Russian].

16. Li, W., Liu, H., Zhou, J.S., Cao, J.F., Zhou, X.B., Choi, A.M., ... \& Shen, H.H. (2012). Caveolin-1 inhibits expression of antioxidant enzymes through direct interaction with nuclear erythroid 2 p45-related factor-2 (Nrf2). Journal of Biological Chemistry, 287 (25), 2092220930.

17. Moskalenko, V.F. (Ed.). (2009). Biostatystyka: pidruchnyk [Biostatistics: a textbook]. Kyiv: Knyha plius [in Ukrainian].

П. Я. Боднар, И. Н. Клищ, Я. Я. Боднар, Т. В. Боднар, Ю. В. Сорока ТЕРНОПОЛЬСКИЙ НАЦИОНАЛЬНЫЙ МЕДИЦИНСКИЙ УНИВЕРСИТЕТ ИМЕНИ И. Я. ГОРБАЧЕВСКОГО МОЗ УКРАИНЫ

\section{СОСТОЯНИЕ ПЕРЕКИСНОГО ОКИСЛЕНИЯ ЛИПИДОВ И АНТИОКСИДАНТНАЯ ЗАЩИТА ПРИ ЭКСПЕРИМЕНТАЛЬНОЙ НЕОПЛАСТИЧЕСКОЙ ИНТОКСИКАЦИИ}

\section{Резюме}

Вступление. Актуальным является вопрос исследования дисбаланса между процессами перекисного окисления липидов и антиоксидантной защиты. Такой дисбаланс вызывает нарушения метаболизма, образование пероксидов, кетонов, альдегидов, его считают основой механизма развития эндогенной интоксикации.

Цель исследования - изучить степень активации перекисного окисления липидов и состояние антиоксидантной защиты при синдроме неопластической интоксикации.

Методы исследования. Использовано фрармакологические, морфологические методы и методы математической статистики. Экспериментальное фрармакологическое исследование выполнено на белых крысах массой 170-180 г в Центральной научно-исследовательской лаборатории Тернопольского национального медицинского университета имени И. Я. Горбачевского МОз Украины (свидетельство об аттестации № 023/13 от 05.03.2020 г.) согласно методическим рекомендациям Государственного экспертного центра МОЗ Украины. При проведении исследования учитывали следующие биохимические показатели крови: активность диеновых и триеновых конъюгатов, среднемолекулярных пептидов (при длине волны 254 и 280 нм), активных продуктов тиобарбитуровой кислоты, супероксиддисмутазы и каталазы. Животных, которых включили в исследование, разделили на 2 группы: 1-я - контрольная; 2-я положительная патология; исследование длилось 30 дней. Моделировали патологические процессы и выводили крыс из эксперимента, соблюдая требования биоэтики, правила надлежащей лабораторной практики, и согласно этическим нормам Европейской конвенции о защите позвоночных животных, которые используются для экспериментальных и других научных целей.

Результаты и обсуждение. В ходе исследования было установлено возрастание биохимических показателей - диеновых и триеновых конъюгатов, активных продуктов тиобарбитуровой кислоты, что указывало на активацию процесса перекисного окисления липидов. Активность супероксиддисмутазы имела колебательный характер и к концу эксперимента уменьшилась на 16,5 \%. Активность каталазы во время эксперимента увеличилась. Показатели MCM $_{254}$ и MCM $_{280}$ повысились, что свидетельствовало о нарастании проявлений эндогенной интоксикации.

Вывод. При синдроме неопластической интоксикации в крови наблюдают постепенное избыточное образование продуктов свободнорадикального окисления в сочетании с компенсаторной активацией энзимных звеньев антиоксидантной системы.

КЛЮЧЕВЫЕ СЛОВА: перекисное окисление липидов; антиоксидантная защита; неопластическая интоксикация. 


\section{THE STATE OF LIPID PEROXIDATION AND ANTIOXIDANT PROTECTION IN EXPERIMENTAL NEOPLASTIC INTOXICATION}

Summary

Introduction. The question of studying the imbalance between the processes of lipid peroxidation and antioxidant protection is relevant. This imbalance causes metabolic disorders, the formation of peroxides, ketones, aldehydes.

The aim of the study - to investigate the degree of activation of lipid peroxidation and the state of antioxidant protection in neoplastic intoxication syndrome. An important issue is the study of the imbalance between the processes of lipid peroxidation and antioxidant protection. This imbalance causes metabolic disorders, the formation of peroxides, ketones, aldehydes and it is the basis of the pathogeneses of endogenous intoxication. We investigated the degree of activation of lipid peroxidation and the state of antioxidant protection in the syndrome of neoplastic intoxication.

Research Methods. Pharmacological, morphological, methods of mathematical statistics. Experimental pharmacological studies were performed on white rats weighing 170-180 g. The studies were performed in the Central Research Laboratory of I. Horbachevsky Ternopil National Medical University of the Ministry of Health of Ukraine (certificate No. 023/13 of May 05, 2020) in accordance with the methodological recommendations of the State Expert Center of the Ministry of Health of Ukraine. We studied the following blood biochemical parameters: the level of diene and triene conjugates, medium molecular weight peptides (at wavelengths of 254 and $280 \mathrm{~nm}$ ), active products of thiobarbituric acid, superoxide dismutase and catalase activity. Rats included in the study were divided into 2 groups: 1 - control group and 2 - positive pathology; the study lasted 30 days. Modeling of pathological processes and withdrawal of animals from the experiment was carried out in compliance with the requirements of bioethics, rules of good laboratory practice and ethical standards of the "European Convention for the protection of vertebrate animals used for experimental or other scientific purposes".

Results and Discussion. The study showed an increase in biochemical parameters of diene and triene conjugates, active products of thiobarbituric acid, which indicates the activation of the peroxidation process. When evaluating the indicators of superoxide dismutase, it was found that its level was fluctuating and by the end of the experiment decreased by $16.5 \%$. The level of catalase increased during the experiment. When studying the indicators of $\mathrm{MMM}_{254}$ and $M \mathrm{MM}_{280}$, their growth was revealed, which indicates an increase in the manifestations of endogenous intoxication.

Conclusion. With the syndrome of neoplastic intoxication in the blood there is a gradual excessive formation of products of free radical oxidation in combination with compensatory activation of enzyme units of the antioxidant system.

KEY WORDS: lipid peroxidation; antioxidant protection; neoplastic intoxication.

Отримано 26.02.21

Адреса для листування: П. Я. Боднар, Тернопільський національний медичний університет імені І. Я. Горбачевського МОз України, майдан Волі, 1, Тернопіль, 46001, Україна, e-mail: bodnarpj@tdmu.edu.uа. 